\title{
Applicability and accuracy of the initially dry and initially wet contact filter paper tests for matric suction measurement of geosynthetic clay liners
}

\author{
A. S. ACIKEL ${ }^{*}$, R. M. SINGH ${ }^{*}$, A. BOUAZZA*, W. P. GATES* and R. K. ROWE
}

\begin{abstract}
An initially wet contact filter paper test (IW-CFPT) and an initially dry contact filter paper test (ID-CFPT) were used to examine the wetting paths of geosynthetic clay liners, including non-contact filter paper tests for comparative purposes. The CFPTs were applied to both geosynthetic clay liner faces to examine the effect of geotextile type on capillary contact. The non-woven geotextile face was found to be more likely to cause capillary breaks than the woven geotextile face. Both IW- and ID-CFPTs were found to be applicable to geosynthetic clay liners within their accurate upper matric suction measurement limits of $146 \mathrm{kPa}$ and $66 \mathrm{kPa}$, respectively.
\end{abstract}

KEYWORDS: geosynthetics; geotextiles; laboratory tests; suction; time dependence

\section{INTRODUCTION}

The primary function of bentonite within a geosynthetic clay liner (GCL) is to create impedance to the flow of migrating liquids, dissolved chemical species and gases or vapours (Bouazza, 2002; Rowe, 2005). This is achieved by the very low permeability of bentonite when fully hydrated after GCL placement, from the underlying or overlying soil (Gates et al., 2009; Bouazza \& Bowders, 2010). When in service, GCLs are often subjected to variable hydration states during initial hydration and thermal cycling, since they are typically manufactured at a low moisture content, yet should be hydrated to $>100 \%$ moisture content to function adequately as a barrier to fluids, and may be exposed to thermal cycles or elevated temperatures (Rowe \& Hoor, 2009; Hornsey et al., 2010; Bouazza et al., 2011, 2013, 2014). Hence, understanding the water retention behaviour of hydrating GCLs is essential to ensure their long-term longevity as hydraulic barriers under adverse conditions.

A limited number of studies have been carried out over the last decade on the water retention behaviour of GCLs using different suction measurement techniques (Abuel-Naga \& Bouazza, 2010; Beddoe et al., 2010, 2011; Bannour et al., 2014; Rouf et al., 2014). Among these techniques, the contact filter paper test (CFPT) is attractive owing to its simplicity and accessibility, but has been used with limited success, primarily related to the accuracy of the suction measurements (Barroso et al., 2006; Acikel et al., 2011). Therefore, a test programme based on the use of initially wet and dry contact filter paper tests (IW-CFPT, ID-CFPT), as well as a non-contact filter paper test (NCFPT) as a reference, was conducted to better adapt the filter paper technique to matric suction measurement of GCLs. IW-CFPT and ID-CFPT tests were performed to evaluate the effect of capillary contact and hysteresis on matric suction measurements. Test

Manuscript received 12 December 2013; revised manuscript accepted 19 May 2015. Published online ahead of print 13 July 2015. Discussion on this paper closes on 1 February 2016, for further details see p. ii.

* Monash University, Melbourne, Australia.

$\dagger$ University of Surrey, Guildford, Surrey, UK.

\$ Queen's University, Kingston, Canada. times of 1 week and 4 weeks were used to investigate the effect of suction equilibrium time on matric suction by IW-CFPT. Standard 1-week ID-CFPT and NCFPTs were conducted as reference tests. All contact tests were applied to both the non-woven cover and woven carrier geotextile faces of the GCLs to investigate the impact of different geotextiles on the capillary contact condition between GCL and filter paper. Filter paper pore size distributions, obtained from scanning electron microscopy (SEM) imaging, provided a sound basis for discussing the results.

\section{Background}

Most filter paper calibration curves (Fawcett \& Collis-George, 1967; Greacen et al., 1987; Chandler et al., 1992a, 1992b; Crilly \& Chandler, 1993; Leong et al., 2002; ASTM, 2010) follow a piecewise defined function considered to be a composite of two functions with a break point at their intersection. Table 1 shows the gravimetric water content of filter papers and corresponding suction values at the break points of the most common filter paper calibration equations recommended for Whatman no. 42 filter paper.

The wetting solid-liquid contact angles of solid-liquid-gas interfaces are considerably larger than their respective drying contact angles, resulting in contact angle hysteresis ( $\mathrm{Lu} \mathrm{\&}$ Likos, 2004). Liukkonen (1997) investigated the wetting properties of paper components by measuring the contact angles of water drops on sample surfaces and by observing microscopic drops in an environmental scanning electron microscope (ESEM). Liukkonen (1997) reported that holocellulose and $\alpha$-cellulose components of dry paper had initial contact angles of, respectively, $56^{\circ}$ and $26^{\circ}$, but both decreased to $0^{\circ}$ with wetting. A contact angle equal to 0 is described as a perfectly wetting material (Lu \& Likos, 2004) or hydrophilic material in the context of geotextiles (Bouazza, 2014).

Lu \& Likos (2004) and Fredlund (2006) described the different saturation zones of a typical water retention curve (WRC) as the boundary effect (capillary fringe) zone, transition (capillary) zone and residual (pendular) zone. Water transfer within the boundary effect zone can occur in the liquid phase, while in the transition zone it can be both 
Table 1. Water content and corresponding suction values of the break points of Whatman no. 42 filter paper calibration equations

\begin{tabular}{c|c|l}
\hline $\begin{array}{c}\text { Water } \\
\text { content: } \%\end{array}$ & $\begin{array}{c}\text { Suction: } \\
\mathrm{kPa}\end{array}$ & \multicolumn{1}{|c}{ Calibration } \\
\hline $45 \cdot 3$ & $66 \cdot 3$ & ASTM D 5298 (ASTM, 2010) \\
$45 \cdot 3$ & $63 \cdot 1$ & Fawcett \& Collis-George (1967) \\
$45 \cdot 3$ & $63 \cdot 3$ & Greacen et al. (1987) \\
47 & $80 \cdot 0$ & Chandler et al. (1992a; 1992b) \\
47 & $82 \cdot 5$ & Crilly \& Chandler (1993) \\
47 & $68 \cdot 0$ & Leong et al. (2002) \\
\hline
\end{tabular}

liquid and vapour phase, but transfer in the residual zone can only be in the vapour phase. Liquid water transfer relies on connected capillarity whereas vapour transfer relies on open pores.

The 'entry' or 'bubbling' pressure of porous media is the threshold pressure for displacement between wetting and nonwetting fluids (Bear, 1972). In the wetting and drying paths under study, the air entry value of a drying curve is the threshold pressure where water is initially replaced by air. Likewise, the water entry value of a wetting curve is the threshold pressure at which air is initially replaced by water (Wang et al., 2000). The suction value between transition and residual zones on the drying curve is defined by residual pressure.

\section{MATERIALS AND METHODOLOGY \\ Materials}

Whatman no. 42 filter papers and a granular bentonite based GCL were used. The needle-punched GCL (Table 2) was composed of a layer of bentonite sandwiched between a woven carrier and a non-woven cover geotextile, with the system being held together by needle punching.

\section{Methods}

Filter paper test. Geosynthetic clay liner specimens were cut at off-roll water contents using a hydraulic press and a sharp stainless steel cutter. The specimens were glued into polyvinyl chloride (PVC) rings $(20 \mathrm{~mm}$ high, $50 \mathrm{~mm}$ internal diameter). They were then hydrated using sterile distilled water to targeted gravimetric water contents. The hydrated specimens were sealed and stored at a constant temperature of $22^{\circ} \mathrm{C}$ under a $1 \mathrm{kPa}$ confining stress for 6 weeks to reach hydration equilibrium throughout the specimen. The ID-CFPT, IW-CFPT and NCFPT procedures were performed on the homogenised specimens. A strict sterilisation procedure (consisting of bleaching and ethanol flash-flaming the testing surfaces and tools, and flaming the surrounding air with a Bunsen burner, as well as using sterile disposable gloves and masks) was followed to minimise any microorganism growth in the system during the tests. Sterile distilled water was used to hydrate the GCL specimens.

Figure 1 shows the IW-CFPT procedure. A stack of three filter papers $(50 \mathrm{~mm}$ protector $-42.5 \mathrm{~mm}$ sensor$50 \mathrm{~mm}$ protector) were placed on both the cover and carrier geotextile faces of the specimens. The sensor filter papers were soaked in sterile distilled water for $1 \mathrm{~h}$ before being used for the IW-CFPT. The only difference between the ID-CFPT and IW-CFPT procedures was the initial gravimetric water content condition of the inner (sensor) filter paper, which was placed between two dry outer (protector) filter papers. In the ID-CFPT the sensor filter paper was dry, whereas in the IW-CFPT the sensor filter paper was saturated. A $1 \mathrm{kPa}$ contact pressure was applied. For the NCFPT, capillary contact was not required, and therefore the filter papers $(42 \mathrm{~cm}$ diameter and oven dried) were used only on the non-woven geotextile side with O-ring separators to prevent contact between GCL and dry

Table 2. Technical properties of the GCL used in the present investigation

\begin{tabular}{|c|c|}
\hline \multicolumn{2}{|l|}{ Mass per unit area: $\mathrm{g} / \mathrm{m}^{2}$} \\
\hline \multicolumn{2}{|l|}{ GCL } \\
\hline Measured & 4698 \\
\hline MARV* & 4000 \\
\hline \multicolumn{2}{|l|}{ Bentonite } \\
\hline Calculated & 4273 \\
\hline MARV* & 3600 \\
\hline \multicolumn{2}{|l|}{ Carrier geotextile } \\
\hline Measured & 126 \\
\hline \multicolumn{2}{|l|}{ Cover geotextile } \\
\hline Measured & 299 \\
\hline \multicolumn{2}{|l|}{ Bentonite } \\
\hline Particle type & Granular \\
\hline Montmorillonite (XRD test results) $\dagger$ & $82 \%$ \\
\hline Initial (off-roll) gravimetric water content & $12 \%$ \\
\hline Liquid limit (ASTM D 4318 (ASTM, 2000)) & $370 \%$ \\
\hline Plastic limit (ASTM D 4318 (ASTM, 2000)) & $36 \%$ \\
\hline Swell indext: ml/2 g (ASTM D 5890 (ASTM, 2011)) & 22 \\
\hline Hydraulic conductivity\$: m/s (ASTM D 5887 (ASTM, 2009a)) & $5 \times 10^{-11}$ \\
\hline \multicolumn{2}{|l|}{ Structure } \\
\hline Configuration (carrier/cover) & $\mathrm{W} / \mathrm{NW}$ \\
\hline Bonding & NP \\
\hline Peel strength: N/m (ASTM D 6496 (ASTM, 2009b))\| & 1247 \\
\hline Thermally treated & No \\
\hline
\end{tabular}

*MARV: minimum average roll value (from producer); SRNW: scrim-reinforced non-woven; W: woven, NW: non-woven; NP: needle-punched.

$\dagger$ XRD tests conducted at CSIRO Land and Water, Mineralogical Services, Adelaide laboratory.

$\$$ Tests were performed on the bentonite specimens extracted from GCLs. Some inevitable remaining fibres might decrease the swell index values.

$\S$ Max. values as provided by the manufacturers.

\|Tests were performed by Geofabrics Australasia, Geosynthetic Centre of Excellence, Queensland. 


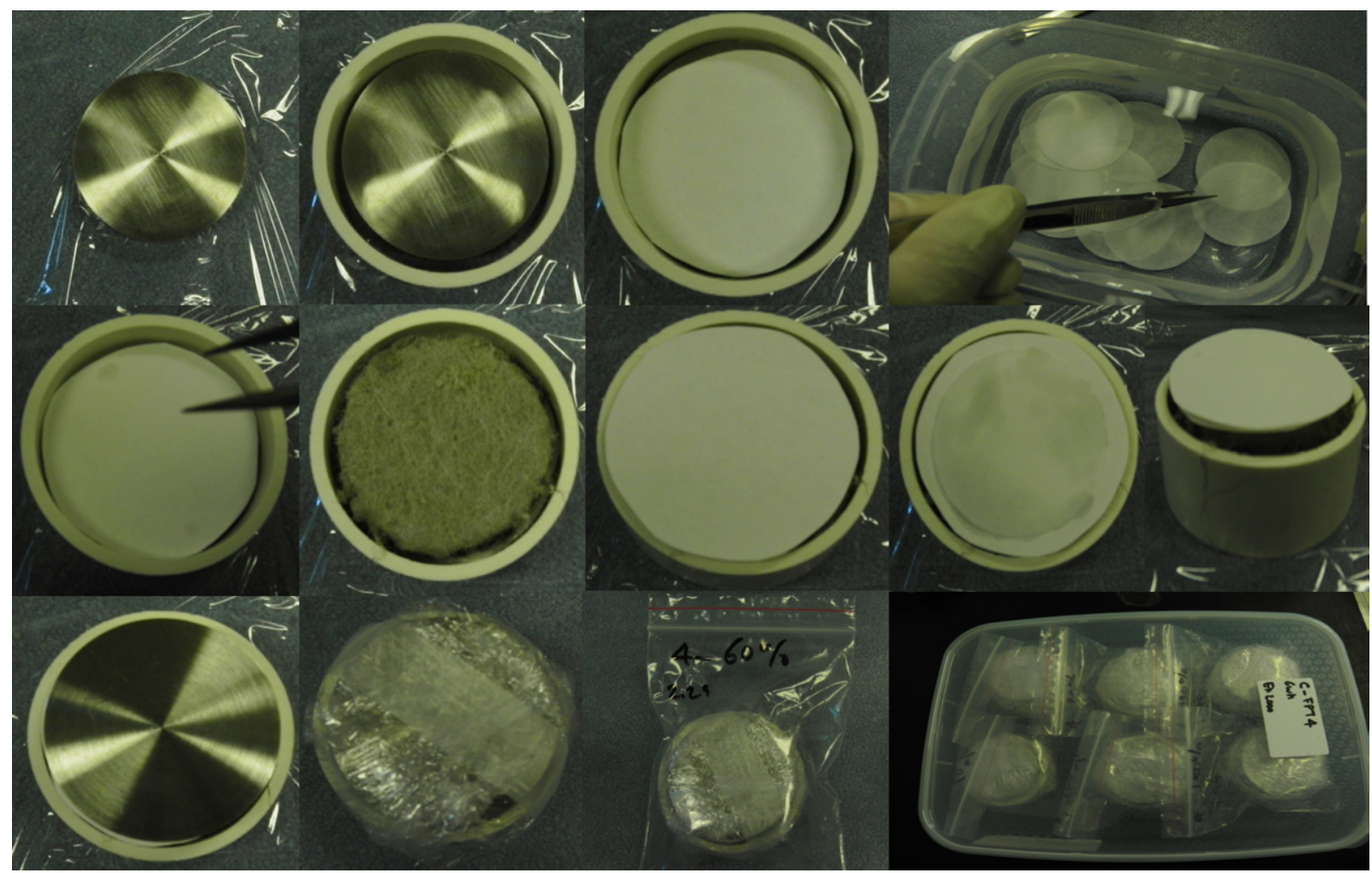

Fig. 1. Initially wet contact filter paper test (IW-CFPT) procedures

protector filter papers (Fig. 2). The specimens were then sealed and kept at a constant temperature of $22^{\circ} \mathrm{C}$ during the tests ( 1 and 4 weeks for IW-CFPT; 1 week for ID-CFPT and NCFPT).
SEM analysis of Whatman no. 42 filter paper. The filter papers were oven dried at $105^{\circ} \mathrm{C}$ overnight. The oven-dried specimens were coated with a very thin layer of iridium to avoid charging during SEM imaging. Then, the pore

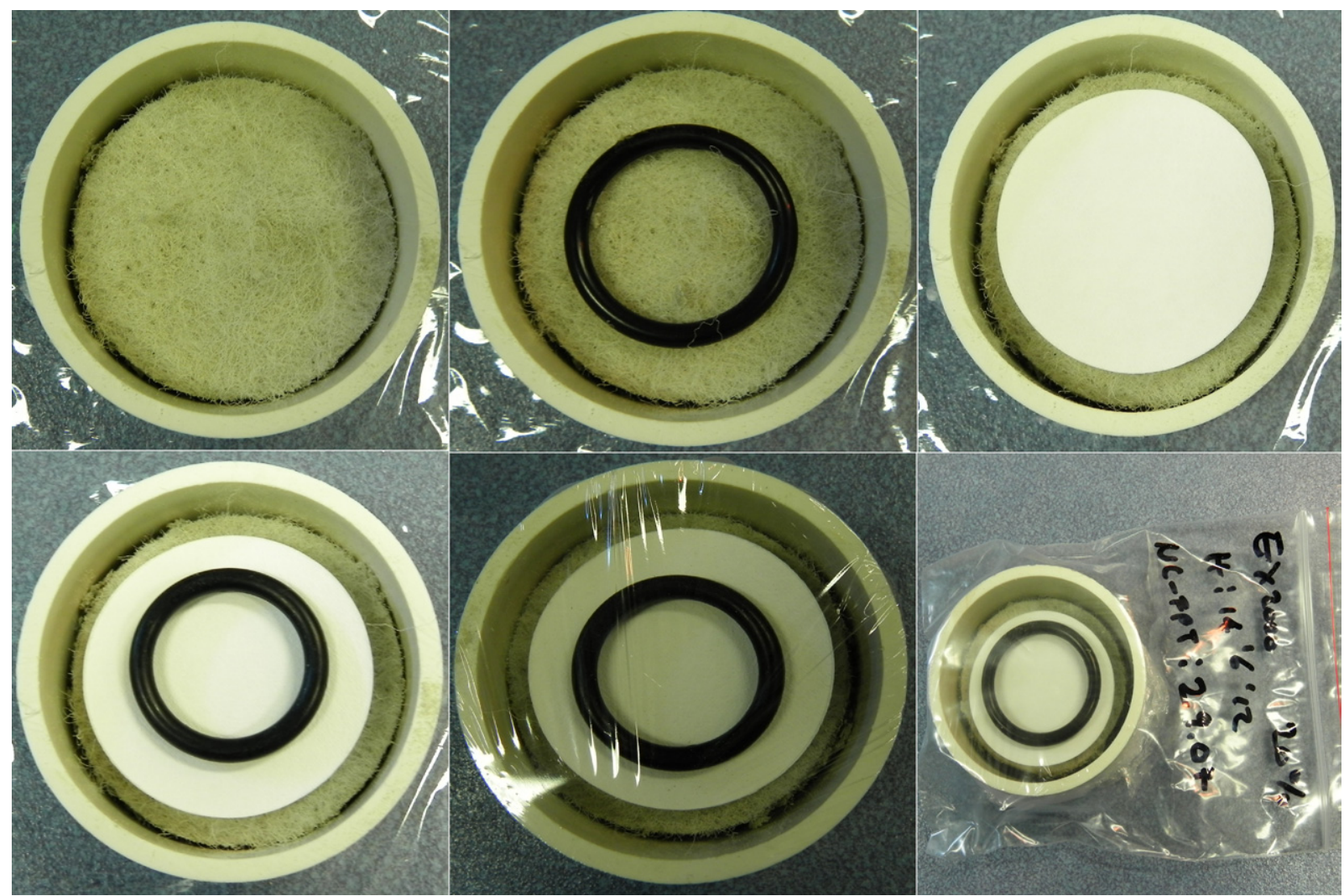

Fig. 2. Non-contact filter paper test (NCFPT) procedures 
sizes were measured from six SEM images by hand. Fig. 3 shows one of the SEM images where the pore sizes were measured.

A distribution analysis was performed on the measured pore size values. Pore sizes larger than $8 \mu \mathrm{m}$ were not taken into consideration for pore size distribution analysis since very few pores exist at this range. The counts of the pore sizes measured from SEM images were extrapolated for a $1 \mathrm{~mm}^{2}$ area. Fig. 4 shows a histogram for the pore size distribution of Whatman no. 42 filter paper. In the filter paper pore size range of $0 \cdot 5-8 \mu \mathrm{m}$, the pores explicitly had a dominant size of $2 \mu \mathrm{m}$.

\section{TEST RESULTS AND DISCUSSION}

Geosythetic clay liner wetting path suction measurement test results calculated using calibration equations recommended by ASTM-D5298 (ASTM, 2010) (Table 3) are presented in Fig. 5. The 1-week ID-CFPT and IW-CFPT gave comparable results for suction values $\sim<70 \mathrm{kPa}$; however, suction values of the ID-CFPT were significantly

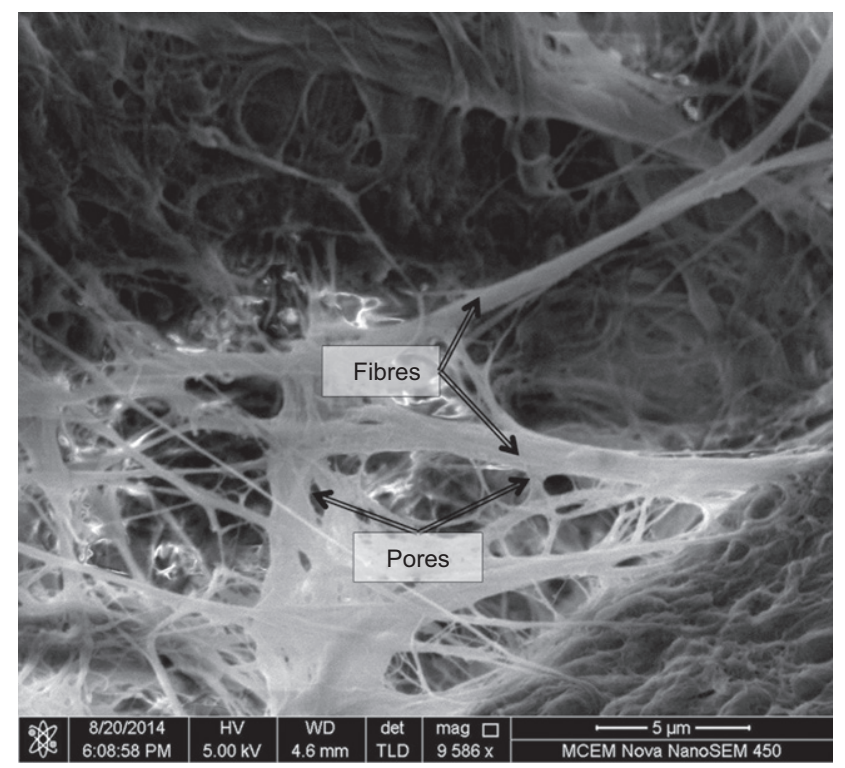

Fig. 3. One of the SEM images of oven-dried Whatman no. 42 filter paper higher compared to those of the IW-CFPT for the suction range $\geq 70 \mathrm{kPa}$. The ID-CFPT results eventually merged with the NCFPT with the increase of the suction values. For the suction range $\leq 100 \mathrm{kPa}$, the 4-week IW-CFPT gave slightly smaller suction values than the 1 -week test. The suction results of CFPT obtained from the cover (non-woven) were greater than those obtained from the carrier (woven) geotextile.

The wetting path matric suction results of CFPTs are compared with wetting and drying path matric suction results reported by Beddoe et al. (2011) for the same GCL using a high-capacity tensiometer (HCT) in Fig. 6. The results of 4-week IW-CFPT applied on the carrier (woven) geotextile are highly comparable with the wetting path results of HCT. Compared to the tensiometer results, the ID-CFPT overestimated the matric suction at values $>70 \mathrm{kPa}$.

Capillary rise in an ideal cylindrical tube is defined by the Young-Laplace equation, which can be expressed as

$$
\Delta p=\frac{4 \gamma \cos \theta}{D}
$$

where $\Delta p$ is capillary pressure, $\gamma$ is surface tension, $\theta$ is contact angle and $D$ is the average effective diameter of pores. The surface tension of water at $22^{\circ} \mathrm{C}$ is $7 \cdot 2 \times$ $10^{-2} \mathrm{~N} / \mathrm{m}$.

The contact angles reported by Liukkonen (1997) were substituted in equation (1) to calculate capillary pressures of Whatman no. 42 filter paper for the particle retention values of the filter paper $(2.5 \mu \mathrm{m})$ reported by the manufacturer as well as the peak pore size $(2 \mu \mathrm{m})$ obtained from the SEM images (Table 4).

Different calibrations of Whatman no. 42 for drying and wetting paths (modified from Munoz-Castelblanco et al. (2012)), drying/wetting path hysteresis, as well as two break points are shown in Fig. 7(a). Fig. 7(b) was generalised from Fig. 7(a) as a conceptual WRC model for filter paper wetting and drying paths assuming filter paper had similar water retention behaviour as soils. According to this conceptual

Table 3. Filter paper calibration equations recommended by ASTM D 5298 (ASTM, 2010)

\begin{tabular}{l|l}
\hline$w<45 \cdot 3$ & $\log _{10}(\psi)=5 \cdot 327-0 \cdot 0779 w^{*}$ \\
$w>45 \cdot 3$ & $\log _{10}(\psi)=2 \cdot 412-0 \cdot 0135 w$ \\
\hline
\end{tabular}

$*_{w}$ is the water content $(\%)$ and $\psi$ is the suction $(\mathrm{kPa})$ of filter paper.

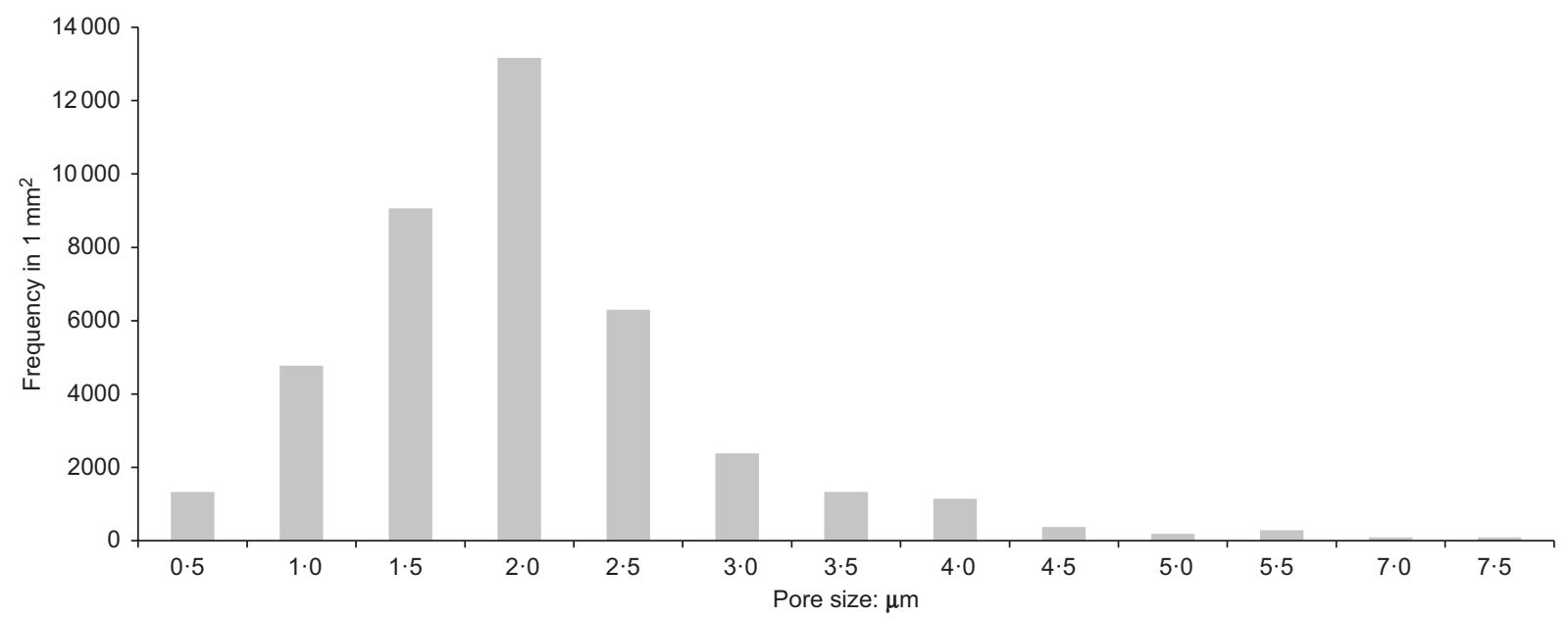

Fig. 4. Pore size distribution of Whatman no. 42 filter paper as determined on pore $<8 \mu \mathrm{m}$ diameter from SEM images (the pore size distribution counts were extrapolated per $\mathbf{m m}^{2}$ ) 


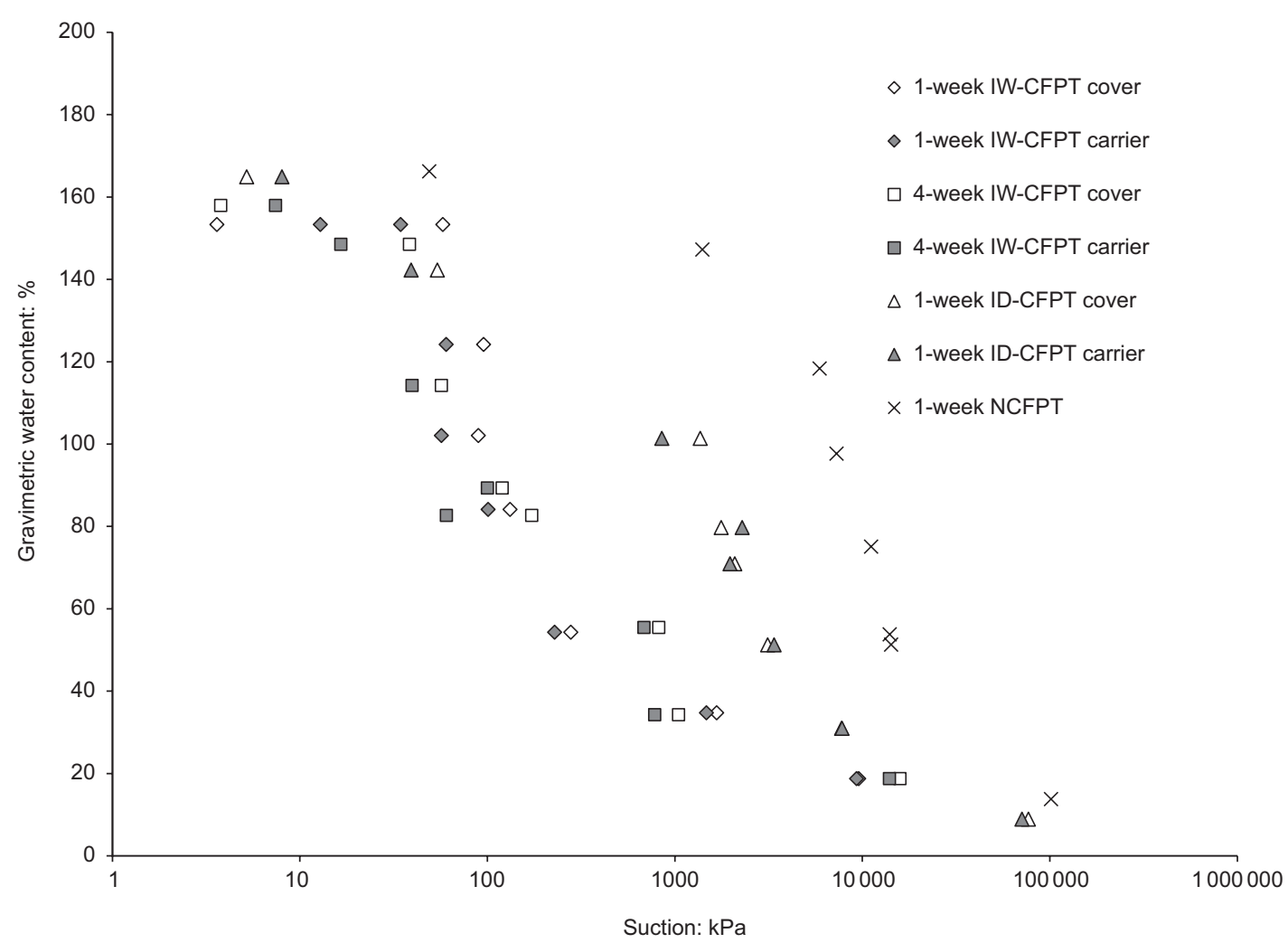

Fig. 5. One- and 4-week initially wet contact as well as 1-week initially dry contact and non-contact filter paper test results of the GCL wetting path

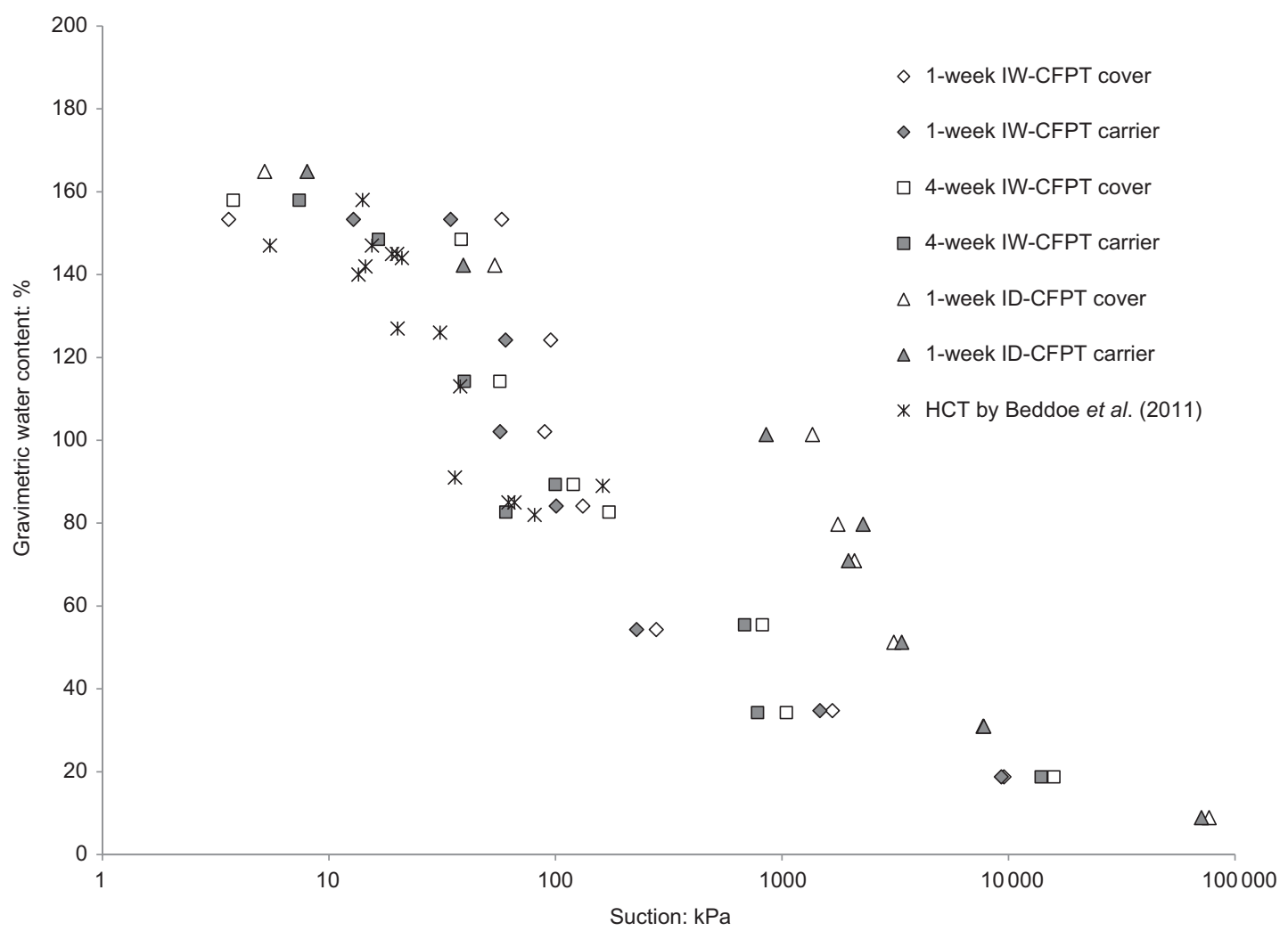

Fig. 6. Comparison of wetting path suction measurements of 1-week and 4-week initially wet contact filter paper tests, as well as 1-week initially dry contact filter paper tests with measurements of HCT by Beddoe et al. (2011) for the wetting path of the same GCL type

model the drying curve break point corresponds to residual pressure (the inflection point between residual and transition zones) of the drying path WRC, and similarly the wetting curve break point corresponds to the water entry value of wetting path WRC. The break point of the drying (initially wet) and wetting (initially dry) curves (Fig. 7(a)) correspond 
Table 4. Capillary pressure values calculated using the Young-Laplace equation (equation (1)) for possible filter paper pore sizes and contact angles

\begin{tabular}{|c|c|c|c|}
\hline \multirow[t]{2}{*}{ Capillary pressure: $\mathrm{kPa}$} & \multicolumn{3}{|c|}{ Contact angles: degrees } \\
\hline & 0 & 26 & 56 \\
\hline \multicolumn{4}{|l|}{ Pore size: $\mu \mathrm{m}$} \\
\hline 2 & 144 & 130 & 81 \\
\hline $2 \cdot 5$ & 116 & 104 & 65 \\
\hline
\end{tabular}

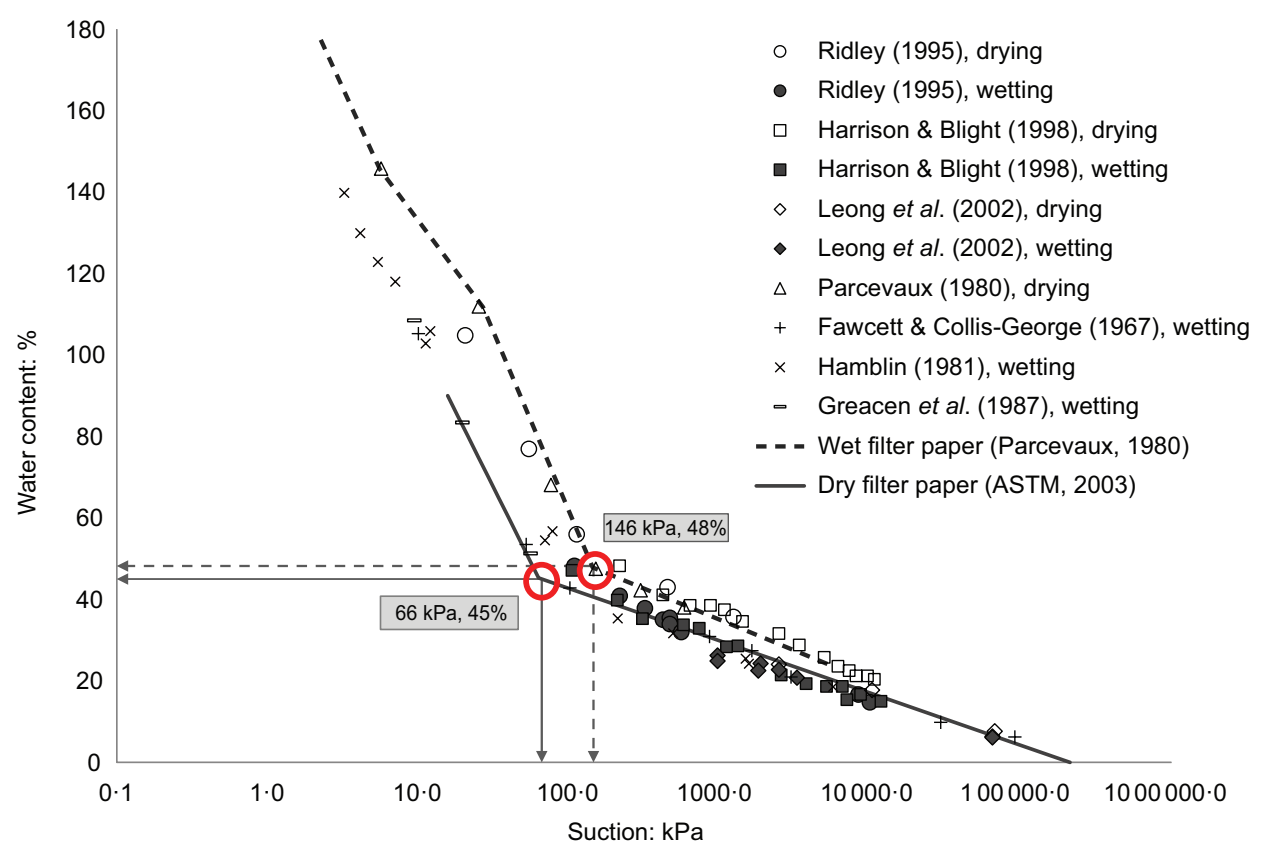

(a)

\begin{tabular}{|c|c|c|}
\hline \multirow{2}{*}{$\begin{array}{c}\text { Capillary pressure by } \\
\text { Young-Laplace equation }\end{array}$} & $\begin{array}{c}\text { During water entry } \\
\left(\theta=56^{\circ}, D=2.5 \mathrm{~mm}\right)\end{array}$ & $\begin{array}{c}\text { After water entry } \\
\left(\theta=0^{\circ}, D=2.0 \mathrm{~mm}\right)\end{array}$ \\
\cline { 2 - 3 } & $65 \mathrm{kPa}$ & $144 \mathrm{kPa}$ \\
\hline
\end{tabular}

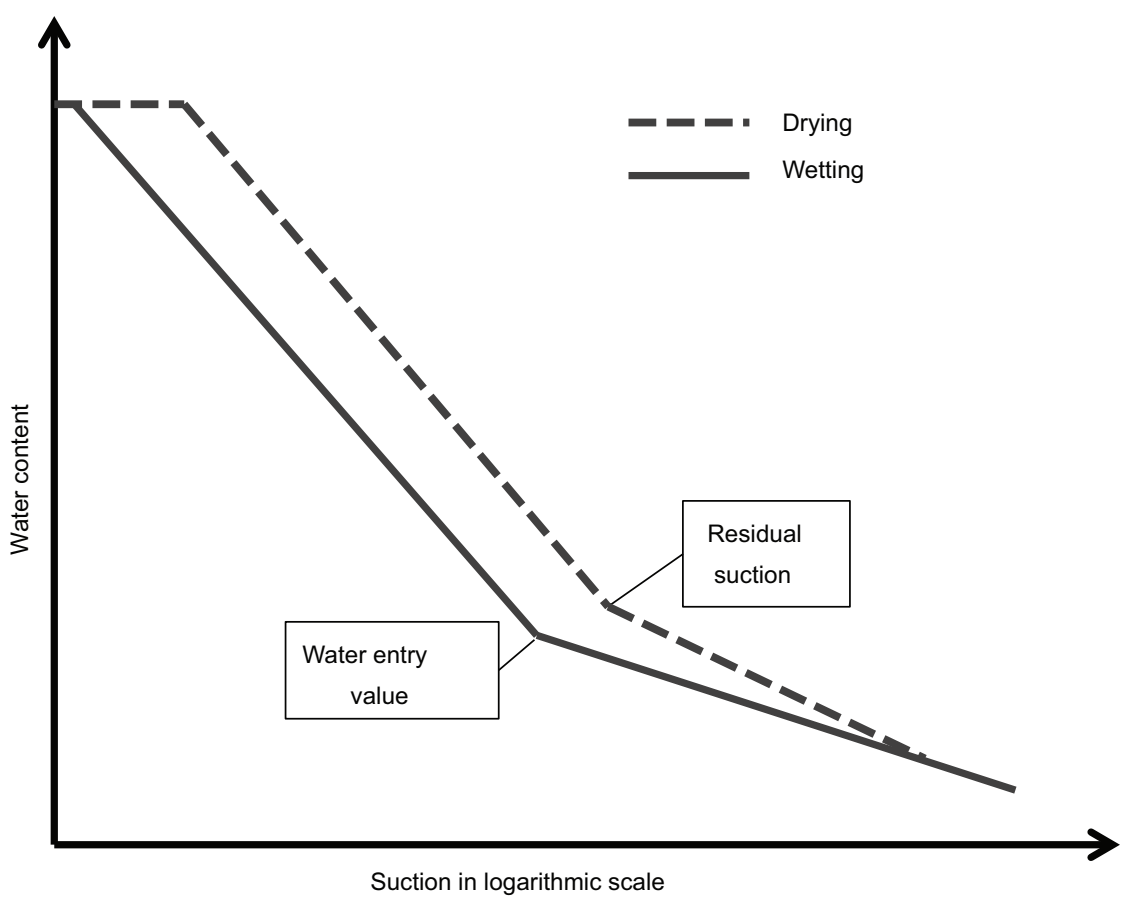

(b)

Fig. 7. (a) Calibration curves for Whatman no. 42 filter paper (modified from Munoz-Castelblanco et al. (2012)) (the two larger circles show the break points). (b) Conceptual model of filter paper water retention behaviour and hysteresis between wetting and drying paths 
approximately to suctions of $146 \mathrm{kPa}(w=48 \%)$ and $66 \mathrm{kPa}$ $(w=45 \%)$, respectively. The Young-Laplace equation gives $144 \mathrm{kPa}$ (Table 4) for the wet case $\left(\theta=0^{\circ}, D=2 \cdot 0 \mu \mathrm{m}\right)$, which is very close to the suction value at the break point of the initially wet calibration curve, $146 \mathrm{kPa}$. The suction values at the break points presented in Table $1(63 \cdot 1-82 \cdot 5 \mathrm{kPa})$ correspond to the calculated capillary pressure values of $65 \mathrm{kPa}$ and $81 \mathrm{kPa}$ for a dry contact angle of $56^{\circ}$ (Table 3 ). The wetting path (initially dry) break point in Fig. 7(a) also corresponds to the calculated capillary pressure for an initially dry contact angle of $56^{\circ}$ and particle retention value $(2 \cdot 5 \mu \mathrm{m})$.

Since the CFPT requires capillary contact between GCL specimen and filter paper, the inflection point between the residual-transition zones of the drying curve and the water entry value of the wetting curve should give the accurate matric suction measurement limits of IW-CFPT and ID-CFPT, respectively. The requirement of capillary contact also explains why IW-CFPT and ID-CFPT gave comparable results up to $\sim 70 \mathrm{kPa}$, which coincides with the accurate measurement limit of ID-CFPT. The suction results of both CFPTs have eventually merged with the NCFPT results after the proposed limit values of 146 and $66 \mathrm{kPa}$ were passed.

The contact test suction values from non-woven cover geotextile side (Figs 5 and 6) merged with the values of NCFPT at lower suctions. This result indicates that the non-woven geotextile used had higher tendency to provide a capillary break than the woven geotextile.

\section{CONCLUSIONS}

Initially dry and wet contact filter paper test (ID-CFPT and IW-CFPT) methodologies were found to be applicable for GCL matric suction measurements. The ID-CFPT (the ASTM standard contact filter paper test) and IW-CFPT methods had theoretical measurement limits of $\sim 66 \mathrm{kPa}$ and $\sim 146 \mathrm{kPa}$, respectively, based on measured pore size distributions of the filter paper used. The 4-week IW-CFPT applied to woven geotextile faces is recommended for matric suction measurement using the filter paper method for GCLs on the wetting path. A non-woven geotextile was found to be more likely to act as a capillary break than a woven geotextile.

\section{ACKNOWLEDGEMENTS}

This research was supported through the Linkage Projects funding scheme (project number LP 0989415) with governmental funding provided by the Austsralian Research Council and industry funding provided by Geofabrics Australasia Pty Ltd. The first author was partially funded by Monash University. The authors are grateful for this support.

\section{REFERENCES}

Abuel-Naga, H. M. \& Bouazza, A. (2010). A novel laboratory technique to determine the water retention curve of geosynthetic clay liners. Geosynthetics Int. 17, No. 5, 313-322.

Acikel, A. S., Singh, R. M., Bouazza, A., Gates, W. P. \& Rowe, R. K. (2011). Water retention behaviour of unsaturated geosynthetic clay liners. Proceedings of 13th international conference of the International Association for Computer Methods and Advances in Geomechanics, Melbourne, Victoria, Australia, vol. 2, pp. 626-630.

ASTM (2000). D 4318: Standard test methods for liquid limit, plastic limit, and plasticity index of soils. West Conshohocken, PA, USA: ASTM International.

ASTM (2003). D 5298: Standard test method for measurement of soil potential (suction) using filter paper. West Conshohocken, PA, USA: ASTM International.
ASTM (2009a). D 5887: Standard test method for measurement of index flux through saturated geosynthetic clay liner specimens using a flexible wall permeameter. West Conshohocken, PA, USA: ASTM International.

ASTM (2009b). D 6496: Standard test method for determining average bonding peel strength between the top and bottom layers of needle-punched geosynthetic clay liners. West Conshohocken, PA, USA: ASTM International.

ASTM (2010). D 5298: Standard test method for measurement of soil potential (suction) using filter paper. West Conshohocken, PA, USA: ASTM International.

ASTM (2011). D 5890: Standard test method for swell index of clay mineral component of geosynthetic clay liners. West Conshohocken, PA, USA: ASTM International.

Bannour, H., Stoltz, G., Delage, P. \& Touze-Foltz, N. (2014). Effect of stress on water retention of needlepunched geosynthetic clay liners. Geotextiles Geomembranes 42, No. 6, 629-640.

Barroso, M., Touze-Foltz, N. \& Saidi, F. K. (2006). Validation of the use of filter paper suction measurements for the determination of GCL water retention curves. Proceedings of the 8th international conference on geosynthetics, Yokohama, Japan, vol. 2, pp. $171-174$.

Bear, J. (1972). Dynamics of fluids in porous media, 2nd edn. New York, NY, USA: Elsevier.

Beddoe, R. A., Take, W. A. \& Rowe, R. K. (2010). Development of suction measurement techniques to quantify the water retention behaviour of GCLs. Geosynthetics Int. 17, No. 5, 301-312.

Beddoe, R. A., Take, W. A. \& Rowe, R. K. (2011). Water-retention behavior of geosynthetic clay liners. J. Geotech. Geoenv. Engng 137, No. 11, 1028-1038.

Bouazza, A. (2002). Geosynthetic clay liners. Geotextiles and Geomembranes 20, No. 1, 3-17.

Bouazza, A. (2014). A simple method to assess the wettability of nonwoven geotextiles. Geotextiles Geomembranes 42, No. 4, $417-419$.

Bouazza, A. \& Bowders, J. J. (2010). Geosynthetic clay liners in waste containment facilities. Rotterdam, the Netherlands: CRC Press/Balkema.

Bouazza, A., Nahlawi, H. \& Aylward, M. (2011). In situ temperature monitoring in an organic-waste landfill cell. J. Geotech. Geoenviron. Engng 137, No. 12, 1286-1289.

Bouazza, A., Zornberg, J., McCartney, J. \& Singh, R. M. (2013). Unsaturated geotechnics applied to geoenvironmental engineering problems involving geosynthetics. Engng Geol. 165, 143-153.

Bouazza, A., Singh, R. M., Rowe, R. K. \& Gassner, F. (2014). Heat and moisture migration in a geomembrane-GCL composite liner subjected to high temperatures and low vertical stresses. Geotextiles Geomembranes 42, No. 5, 555-563.

Chandler, R. J., Crilly, M. S. \& Montgomery-Smith, G. (1992a). A low-cost method of assessing clay desiccation for low-rise buildings. Proc. Inst. Civil Engrs 92, No. 2, 82-89.

Chandler, R. J., Harwood, A. H. \& Skinner, P. J. (1992b). Sample disturbance in London Clay. Géotechnique 42, No. 4, 577-585, http://dx.doi.org/10.1680/geot.1992.42.4.577.

Crilly, M. S. \& Chandler, R. J. (1993). A method of determining the state of desiccation in clay soils. Info. Paper Bldg Res. Est. 4, No. 93, 1-4.

Fawcett, R. \& Collis-George, N. (1967). A filter-paper method for determining the moisture characteristics of soil. Aust. J. Expl Agric. 7, No. 25, 162-167.

Fredlund, D. G. (2006). Unsaturated soil mechanics in engineering practice. J. Geotech. Geoenviron. Engng 132, No. 3, 286-321.

Gates, W. P., Bouazza, A. \& Churchman, G. J. (2009). Bentonite clay keeps pollutants at bay. Elements 5, No. 2, 105-110.

Greacen, E. L., Walker, G. R. \& Cook, P. G. (1987). Evaluation of the filter paper method for measuring soil water suction. Proceedings of the international conference on measurement of soil and plant water status, Logan, UT, USA, pp. 137-143.

Hamblin, A. P. (1981). Filter-paper method for routine measurement of field water potential. J. Hydrol. 53, No. 3-4, 355-360.

Harrison, B. A. \& Blight, G. E. (1998). The effect of filter paper and psychrometer calibration techniques on soil suction measurements. Proceedings of the 2nd international conference on unsaturated soils, Beijing, China, pp. 362-367.

Hornsey, W. P., Scheirs, J., Gates, W. P. \& Bouazza, A. (2010). The impact of mining solutions/liquors on geosynthetics. Geotextiles 
Geomembranes 28, No. 2, 191-198, doi: 10.1016/j.geotexmem. 2009.10 .008

Leong, E. C., He, L. \& Rahardjo, H. (2002). Factors affecting the filter paper method for total and matric suction measurements. Geotech. Testing J. 25, No. 3, 322-333.

Liukkonen, A. (1997). Contact angle of water on paper components: Sessile drops versus environmental scanning electron microscope measurements. Scanning 19, No. 6, 411-415.

Lu, N. \& Likos, W. J. (2004). Unsaturated soil mechanics. New York, NY, USA: John Wiley.

Munoz-Castelblanco, J. A., Pereira, J. M., Delage, P. \& Cui, Y. J. (2012). The water retention properties of a natural unsaturated loess from northern France. Géotechnique 62, No. 2, 95-106, http://dx.doi.org/10.1680/geot.9.P.084.

Parcevaux, P. (1980). Etude microscopique et macroscopique $d u$ gonflement de sols argileux. $\mathrm{PhD}$ thesis, Ecole Nationale Supérieure des Mines de Paris, Paris, France (in French).
Ridley, A. M. (1995). Discussion on 'Laboratory filter paper suction measurements' by S. L. Houston, W. N. Houston and A. M. Wagner. Geotech. Testing J. 18, No. 3, 391-396.

Rouf, M. A., Singh, R. M., Bouazza, A., Gates, W. P. \& Rowe, R. K. (2014). Evaluation of a geosynthetic clay liner water retention curve using vapour equilibrium technique. Proceedings of the 6th international conference on unsaturated soils, UNSAT 2014, Sydney, NSW, Australia, vol. 2, pp. 1003-1009.

Rowe, R. K. (2005). Long-term performance of contaminant barrier systems. Géotechnique 55, No. 9, 631-678, http://dx. doi.org/10.1680/geot.2005.55.9.631.

Rowe, R. K. \& Hoor, A. (2009). Predicted temperatures and service lives of secondary geomembrane landfill liners. Geosynthetics Int. 16, No. 2, 71-82.

Wang, Z., Wu, L. \& Wu, Q. J. (2000). Water-entry value as an alternative indicator of soil water-repellency and wettability. J. Hydrol. 231-232, 76-83. 